University at Buffalo School of Law

Digital Commons @ University at Buffalo School of Law

\title{
Neutralizing the Incompetent Voter: A Comment on Cook v. Gralike
}

James A. Gardner

University at Buffalo School of Law

Follow this and additional works at: https://digitalcommons.law.buffalo.edu/journal_articles

Part of the Constitutional Law Commons, and the Election Law Commons

\section{Recommended Citation}

James A. Gardner, Neutralizing the Incompetent Voter: A Comment on Cook v. Gralike, 1 Elec. L.J. 49 (2002).

Available at: https://digitalcommons.law.buffalo.edu/journal_articles/239

\section{C) ${ }_{\text {COPYRIGHT }}^{\text {N }}$}

This Article is brought to you for free and open access by the Faculty Scholarship at Digital Commons @ University at Buffalo School of Law. It has been accepted for inclusion in Journal Articles by an authorized administrator of Digital Commons @ University at Buffalo School of Law. For more information, please contact lawscholar@buffalo.edu. 


\title{
Neutralizing the Incompetent Voter: A Comment on Cook v. Gralike
}

\author{
JAMES A. GARDNER
}

$\mathbf{A}^{2}$ S BOSWELl RELATES in his engaging Life of Johnson, intelligence and conversational wit were highly prized commodities in the salon society of 18th-century London. In that society, the playwright Oliver Goldsmith suffered from an unfortunate handicap. Though a man of great literary accomplishment, Goldsmith, according to Dr. Johnson, was "master of a subject in his study, and can write well upon it; but when he comes into company, grows confused, and unable to talk."1 I suspect that few would think to describe the modern American voter in the way that Johnson described Goldsmith. Yet in a series of decisions rendered over nearly three decades, the United States Supreme Court has developed a political sociology of voting that is distinctly Goldsmithian. In the Court's view, voters are masters of politics in the privacy of their studiesintelligent, assured, competent. Yet when they venture into public to cast their votes, these same voters become unsure, easily flummoxed, and susceptible to suggestion-in a word, incompetent.

This model has led the Court to construe the Constitution to create two entirely different regimes of electoral regulation, one for the private aspects of opinion formation, and another for the more public aspects of casting votes. Under the former regime, best exemplified by Buckley v. Valeo, $^{2}$ the Constitution essentially forbids government regulation of the electoral process when it is premised on the theory that voters might become confused or be subjected

James A. Gardner is Visiting Professor of Law at the State University of New York, University at Buffalo School of Law, and Professor of Law at Western New England College School of Law. Thanks to Rick Hasen and Melissa Saunders for commenting on a previous draft. to improper influence during the course of a political campaign. During the campaign phase, the Court seems to believe, voters can handle themselves. Under the latter regime, in contrast, the Constitution turns out to be highly protective of voters and solicitous of efforts to shield them from attempts to confuse or improperly influence them in the polling place. Here, according to the Court, the voter not only may, but must be handled with great delicacy.

The Court's recent decision in Cook v. Gralike ${ }^{3}$ extends and reinforces this dichotomous approach to voting behavior. In Cook, the Court invalidated a so-called "Scarlet Letter" law that required state election officials to identify on the ballot any candidates for office who refused publicly to pledge support for a constitutional amendment imposing term limits on members of Congress. The Court based this holding on its belief that the ballot designation was an attempt by the state to "dictate electoral outcomes" - a result that is plausible only on the assumption that it is possible to control the way voters vote by the simple expedient of including on the ballot a single piece of accurate, though suggestive, information. This assumption may well be valid, but it contrasts starkly with the assumptions of voter competence and independence the Court seems to make in Buckley and other cases dealing with political campaigns.

I argue below that these two bodies of case law may be reconciled if they are understood to ratify two different methods for neutralizing the effects of irrational voting, one applicable

${ }^{1}$ James Boswell, The Life of Johnson 169 (Penguin 1979) (1791)

2424 U.S. 1 (1976) (per curiam).

${ }^{3} 121$ S.Ct. 1029 (2001). 
to campaigns and the other to the polling place. Even if irrational voting is an irrevocable fact of contemporary electoral politics, electoral outcomes themselves need not be irrational if the effect of irrational votes can be neutralized by distributing them evenly among the candidates. During a long campaign in which all candidates campaign hard for the votes of rational and irrational voters alike, it may be plausible to expect that irrational voters will distribute themselves among the candidates approximately evenly, thereby neutralizing their impact on the outcome of the election. However, when candidates appeal to irrational voters in the polling place, other candidates have no opportunity to make counter-appeals, raising the possibility that some candidates will gain decisive windfalls of irrational votes. Because, on this view, irrational voters cannot easily harm the electoral process during the campaign phase, there is no great need to regulate their exposure to campaign information. Conversely, such voters can harm the process when influenced at the polling place, thereby justifying careful regulation of the presentation of information in that setting.

\section{VOTING BEHAVIOR IN THE COURT}

\section{The Buckley tradition}

Buckley has had such a monumental impact on election law for so long that it is easy to forget what Congress was originally trying to accomplish with the Federal Election Campaign Act (FECA). Buckley has come to stand for the proposition that the main congressional goal in limiting campaign spending was to minimize the possibility of quid pro quo corruption of elected officials. Yet that was only one goal of the legislation, and a secondary goal at that. Congress' main concern in enacting FECA was its conviction that the influx into the campaign process of large amounts of money was causing voters to vote, and elections to be decided, for improper reasons. As one report accompanying an early draft of FECA put it, "candidates [should be] competing for votes of the electorate on their merits rather than on the basis of exposure as in the case of such commodities as toothpaste, soft drinks and beer, aspirin and razor blades." ${ }^{4}$ On the Senate floor, Senator Muskie defended the proposed legislation on the ground that "millions are spent to sweep men into office on a wave of superficial advertising more appropriate to soap or cereal than national politics." 5

What these and many other comments ${ }^{6}$ reveal is a deep congressional fear that campaign money plays a significant and improper role in determining the way people vote. By limiting campaign expenditures in FECA, Congress expressed a belief that voters do not always vote rationally-on the basis of a careful, detached, intelligent review of all pertinent information. Instead, voters, or at least some voters, often decide how to vote among candidates for political office in the same way that they decide what toothpaste to buy: without conscious reflection, on the basis of superficial or improper criteria, or in response to the sheer weight of repeated exposure to advertising. It is less clear whether Congress thought that unlimited campaign spending created an irrational voting problem where none had previously existed, exacerbated an existing problem, or simply allowed the better-financed candidate to attract more irrational votes. Either way, Congress obviously felt that equalizing the amount of money available to candidates would improve the rationality of the electoral process.

The Court's response to this theory is notorious. Treating political spending as a form of speech, the Court, in language worthy of Milton, cast out the incompetent voter rationale from the pantheon of legitimate justifications for regulating electoral processes: "the concept that government may restrict the speech of some elements of our society in order to enhance the relative voice of others," thundered the Court, "is wholly foreign to the First Amendment."7 In subsequent cases, the Supreme Court and lower federal courts have construed this language to establish a virtually irrebuttable presumption that in election campaigns more information is always good. This presumption holds regardless of the identity or interests of the speaker; ${ }^{8}$

\footnotetext{
${ }^{4}$ H.R. Rep. No. 565, 92d Cong., 1st Sess. 19 (1971).

5117 Cong. Rec. 29,321 (1971).

6 See also id. at 29,322 (Sen. Talmadge), 30,072 (Sen. Hart), 42,063 (Rep. Staggers), 42,056 (Rep. Madden), 42,068 (Rep. Conte), 42,072 (Rep. Thompson), and 42,076 (Rep. Ichord). 7424 U.S. at $48-49$.

${ }^{8}$ First National Bank of Boston v. Bellotti, 435 U.S. 765 (1978).
} 
regardless of whether the information is misleading, ${ }^{9}$ or even false; ${ }^{10}$ and regardless of whether the information might unduly influence voter opinion, ${ }^{11}$ or distort the electoral process by artificially depressing turnout. ${ }^{12}$

At work here is an evident assumption that voters are both capable and exceptionally hardy. They understand information communicated to them during political campaigns, and can evaluate it intelligently. They can sift through the available information, distinguishing the true from the false and the good from the bad. They can attach to each piece of information just the weight it deserves, ignoring irrelevancies such as slick packaging, pandering slogans, and the frequency with which any particular message is communicated. They understand when information made available to them is one-sided, and discount it accordingly. ${ }^{13}$ Voters, on this view, are rational, competent, and self-sufficient-they are paragons of democratic citizenship. ${ }^{14}$

\section{Cook and the campaign-polling place divide}

The Cook case. In Cook v. Gralike, a candidate for Congress challenged a provision of the Arkansas Constitution regulating the form and content of the ballot to be used in elections for federal offices. After the Supreme Court held in U.S. Term Limits, Inc. v. Thornton ${ }^{15}$ that members of Congress could be subjected to mandatory term limits only upon amendment of the United States Constitution, advocacy groups supporting term limits began to devote their energies to building support for such an amendment. As the result of effective grass-roots organizing, some states adopted measures, usually through citizen initiative lawmaking, requiring candidates for office to pledge to support a constitutional amendment limiting congressional terms. Like many of these "Scarlet-Letter" provisions, ${ }^{16}$ the Arkansas version directed that the phrase "DISREGARDED VOTERS' INSTRUCTION ON TERM LIMITS" be printed on the ballot adjacent to the name of any incumbent official who failed to take a series of designated steps intended to further the term limit amendment cause. Nonincumbent candidates were asked to take a pledge to support a constitutional amendment, and the name of any candidate who refused to do so would be printed on the ballot along with the phrase "DECLINED TO PLEDGE TO SUP-
PORT TERM LIMITS." The Court invalidated the Arkansas provision on the ground that it exceeded the state's power under Article I, § 4 of the U.S. Constitution to regulate the "Times, Places and Manner of holding Elections for Senators and Representatives."17

${ }^{9}$ Vanasco v. Schwartz, 401 F. Supp. 87 (E.D.N.Y. 1975) (three-judge court), aff'd, 423 U.S. 1041 (1976).

${ }^{10}$ Monitor Patriot Co. v. Roy, 401 U.S. 265 (1971); but see Garrison v. Louisiana, 379 U.S. 64, 75 (1964) (suggesting in dicta that calculated falsehoods, even when not directed at individuals, may enjoy no First Amendment protection).

${ }^{11}$ Mills v. Alabama, 384 U.S. 214 (1966).

12 The Daily Herald Co. v. Munro. 838 F.2d 380 (9th Cir. 1988).

13 The same set of assumptions sometimes appears in other contexts. For example, in Planned Parenthood of Southeastern Pennsylvania v. Casey, 505 U.S. 833 (1992), the Court upheld a state law requiring that women seeking abortions be given information about alternatives to abortion, and then undergo a waiting period, presumably for the purpose of reviewing the literature. The Court was not moved by the argument that this amounted to a forcefeeding of propaganda that might unduly influence a pregnant woman's decision making process at a vulnerable moment. Instead, women seeking abortions were viewed as rational, detached consumers of information, much like the voters sketched in Buckley.

${ }^{14}$ Daniel Ortiz calls such voters "civic smarties." Daniel R. Ortiz, The Engaged and the Inert: Theorizing Political Personality under the First Amendment, 81 VA. L. Rev. 1 (1995). 15514 U.S. 779 (1995).

${ }^{16}$ Such provisions have a distinguished pedigree. For example, in Conley v. Hardwick, 132 S.W. 140 (Ky. 1910), the court invalidated the results of a referendum on the local sale of liquor. The "No" vote spot on the ballot was accompanied by a picture of the Bible; the "Yes" vote spot contained a picture of a snake crawling out of a whiskey bottle.

${ }^{17}$ Every other court to consider a Scarlet Letter initiative also concluded it was unconstitutional, though the U.S. Supreme Court was the only court to rule on Art. I, $\S 4$ grounds. The lower courts concluded that these measures violate the provisions of Article $\mathrm{V}$ governing amendment of the U.S. Constitution. In reaching these results, however, they shared the Supreme Court's belief that such measures improperly coerce legislators to vote to support a constitutional amendment. The measures were seen as coercive because of their likely effectiveness in influencing voters. See Bramberg v. Jones, 978 P.2d 1240 (Cal. 1999); Miller v. Moore, 169 F.3d 1119 (8th Cir. 1999); Morrissey v. Colorado, 951 P.2d 911 (Colo. 1998); Barker v. Hazeltine, 3 F. Supp.2d 1088 (D.S.D. 1998); League of Women Voters of Maine v. Gwadosky, 966 F. Supp.52 (D. Me. 1997); Donovan v. Priest, 931 S.W.2d 119 (Ark. 1996), cert. denied, 519 U.S. 1149 (1997); In re Initiative Petition No. 364, 930 P.2d 186 (Okla. 1996); Opinion of the Justices, 673 A.2d 693 (Me. 1996). In contrast, the Idaho Supreme Court struck down such a law on the ground that it violated the Speech and Debate Clause and infringed upon protected First Amendment speech rights of candidates. In re Simpson v. Cenarrusa, 944 P.2d 1372 (Idaho 1997). 
At first glance, Cook and Buckley seem similar. Both seem to prohibit government interference with the process by which voters formulate and officially express their political inclinations. At a deeper level, however, the two cases are very different, as the Court's reasoning in Cook reveals. The main difficulty with the Arkansas ballot regulation, the Court explained, is that Arkansas had improperly used its power to regulate elections to " 'dictate electoral outcomes.' "18 The provision did so by disfavoring candidates who oppose term limits. The ballot labels, said the Court, impose "substantial political risk" on candidates who fail to comply. ${ }^{19}$ The Arkansas provision also contained another flaw: " 'by directing the citizen's attention to the single consideration' of the candidates' fidelity to term limits, the labels imply that the issue is 'an important-perhaps paramount-consideration in the citizen's choice, which may decisively influence the citizen to cast his ballot' against candidates branded as unfaithful."20

In light of Buckley, this reasoning is startling and, if Buckley's assumptions are well-founded, unconvincing. If voters are smart enough and savvy enough to weigh and evaluate the mass of information communicated to them during a congressional campaign, how is it possible that the presentation of one additional piece of information on the ballot-a piece of information, moreover, that the informed voter would surely already know- "dictate" any voter's vote? One might have thought that under Buckley, providing information to voters during an election should be deemed an unqualified good. ${ }^{21}$ The competent, informed voter sketched in Buckley will take the information on the ballot for whatever it is worth-not much, presumably-and go about his or her business. At the very least, Cook seems to readmit a proposition that Buckley sought to banish from the constitutional analysis: the idea that providing information to voters during an election is capable of coercing their votes, thereby controlling electoral outcomes.

The fact that the ballot labels deal with only a single piece of information also seems, in light of Buckley, of little relevance. Much and perhaps most political speech draws voters' attention to a single issue, especially when it is repeated over and over. Such appeals during campaigns certainly may and probably do "decisively influence" citizens in their voting decisions, but Buckley views this as inconsequential. Moreover, the subject to which the Arkansas ballot labels draw the voter's attention is an entirely legitimate basis for political decision making. This distinguishes Cook from Anderson v. Martin, ${ }^{22}$ in which the Court struck down a state law requiring that the race of each candidate be printed on the ballot. It is one thing to invite voters to vote on the basis of race, a constitutionally suspect characteristic, and another thing altogether to suggest that they consider a mainstream, legitimately contested political issue.

The Court's reasoning also fails to distinguish the ballot labels from other information that is routinely and, one assumes, uncontroversially provided on the ballot. Most ballots identify the political party to which candidates belong. A candidate's party affiliation is a single piece of information to which the state draws voters' attention by printing it on the ballot. Indeed, listing party affiliation is merely a shorthand way of listing a bundle of policy commitments held by the affiliated candidate. This makes it unlikely that the defect in the Arkansas ballot label law could have been the sin of providing information on the ballot about candidates' substantive positions. Moreover, party affiliation is also a piece of infor-

18121 S.Ct. at 1038 , quoting U.S. Term Limits, 514 U.S. at 833-34.

${ }^{19}$ Id. at 1039.

${ }^{20}$ Id., quoting Anderson v. Martin, 375 U.S. 399, 402 (1964).

${ }^{21}$ In a recent article, Beth Garrett offers a theoretical defense of ballot labels on the ground that they may provide useful information to voters, although she concludes that such labels are in practice too susceptible to manipulation. Elizabeth Garrett, The Law and Economics of "Informed Voter" Ballot Notations, 85 VA. L. Rev. 1533 (1999). Garrett's theoretical defense, however, relies on a Downsian model of voting behavior in which voters rationally limit their intake of campaign information, relying primarily on a few useful cues and heuristics such as party affiliation and incumbency. This is a very different model than the Court uses in Buckley, for if the Court thought voters behaved according to the Downsian model, there would be little need for it so aggressively to protect voters' access to unlimited campaign information. Garrett's approach, which acknowledges the possibility of unfair manipulation of voting cues, thus better explains the outcome in Cook than in Buckley.

22375 U.S. 399 (1964). 
mation that has a great capacity to "dictate electoral outcomes." There are many jurisdictions in which having the word "Democrat" or "Republican" printed next to one's name all but guarantees electoral defeat. Yet it seems clear that no candidate could successfully object to a state law requiring disclosure on the ballot of party affiliation.

If the defect in Cook was that the ballot only contained information on a single issue position taken by the candidates, we might wonder whether Arkansas could cure the defect by listing candidates' positions on three or four other issues. The answer to this question is of no small importance. The Court's decision in Bush v. Gore $^{23}$ renewed interest nationwide in developing more sophisticated voting technology. Computerized voting systems could easily allow the ballot to contain links to campaign literature, permitting voters to browse pertinent information right in the voting booth. Indeed, it is difficult to see how doing so would be any different from providing voters with an official voter information pamphlet, as California has long done without encountering any serious constitutional difficulties. Buckley suggests in the strongest possible terms that all information provided to voters improves the political decision making process, ${ }^{24}$ and it is difficult on that assumption to see the precise problem with the Arkansas law invalidated in Cook.

One additional possibility is suggested by Chief Justice Rehnquist in his concurrence. According to the Chief Justice, one of the main vices of the Arkansas ballot labels is that they appear on the ballot, which is "the last thing the voter sees before he makes his choice." The problem with this arrangement is that "[t]he candidates who are thus singled out have no means of replying to their designation which would be equally effective with the voter." 25 This argument is undoubtedly correct-but only on assumptions very different from those made in Buckley, an opinion to which the Chief Justice seems otherwise deeply committed. ${ }^{26}$

Under the reasoning of Buckley, it is simply incorrect to say that candidates have no opportunity to reply to information about their position on term limits. They have the entire campaign period in which to discuss and de- fend their positions on this and any other issue. It is true that candidates have no opportunity to reply to voters in the voting booth, but Buckley voters would not be influenced in any way as a result. Buckley voters will doubtless have determined for themselves during the campaign what importance to attach to term limits as an election issue, what they think of the candidates' positions on term limits, and how that will affect their votes. Such voters will take the ballot designation for what it is worth-nothing-and vote their inclinations anyway. The Court, it should also be noted, had no trouble in Mills v. Alabama ${ }^{27}$ striking down a state law prohibiting newspapers from publishing editorials endorsing candidates on election day. The state defended the law on precisely the same grounds as Chief Justice Rehnquist invoked in Cook: that it protected candidates from damaging election-related attacks under circumstances precluding any possibility of reply.

Protection of voters at the polling place. In a substantial body of cases dealing with elections, Cook is only the third case, along with $\mathrm{An}$ derson v. Martin and Burson v. Freeman, ${ }^{28}$ in which the Court has authorized the suppression of accurate political information during an election. That seems to bring it into tension with the Buckley line of cases. Nevertheless, Cook fits comfortably into another line of cases, one evincing consistent judicial concern with

${ }^{23} 121$ S.Ct. 525 (2000).

${ }^{24}$ See Ortiz, supra note 14 , at 13 (according to such a reading of Buckley, "money is to be celebrated because it gets more information and more ideas out to voters").

25121 S.Ct. at 1042.

${ }^{26}$ For example, he voted with the majority in Nixon v. Shrink Missouri Government PAC, 528 U.S. 377 (2000), declining to join Justices Kennedy, Thomas and Scalia, who called for overruling Buckley's upholding of contribution limits. On the other hand, he has consistently approved of restrictions on corporate expenditures, which Buckley viewed suspiciously, dissenting in First National Bank of Boston v. Bellotti, 435 U.S. 765 (1978), and joining the majority in Austin v. Michigan State Chamber of Commerce, 494 U.S. 652 (1990).

27384 U.S. 214 (1966).

28504 U.S. 191 (1992). In Burson, the Court sustained a state law barring electioneering within one hundred feet of the polling place. 
improper influence on voters at the polling place. In these cases, federal courts have repeatedly construed the Constitution to permit state regulation designed to protect voters from confusion and other improper influences to which they may be subjected in the act of voting itself.

This body of law seems to have its genesis in early government responses to violence and outright fraud at the polling place. In the eighteenth century and well into the nineteenth, elections were not infrequently bloody affairs. Physical threats sometimes kept voters from attempting to vote at all, or coerced them into voting in a particular way. Following Reconstruction, much of this violence was directed against blacks attempting to exercise their newly granted political rights. In the Enforcement Act of $1870,{ }^{29}$ intended to enforce the Fifteenth Amendment, Congress prohibited the use of force, bribery, threats and intimidation to interfere with voting at federal elections. In a series of opinions beginning in 1879,30 the Court sustained these and similar provisions as appropriate exercises of congressional power to protect the integrity of elections.

Legislative attention to the voting process soon broadened once the most immediate problems of overt violence were adequately controlled. The Progressives, in particular, were deeply concerned with the ability of democratic citizens to make intelligent and rational political decisions, and they saw violence as only the most obvious manifestation of a more general threat to intelligent self-governance posed by various kinds of illicit influences and voter confusion. For example, Progressives instituted an extremely successful nationwide campaign against the long ballot, which they believed to be so unwieldy and confusing as to tax the abilities of even the most competent citizens. As a result, all states now have elaborate ballot access laws that significantly restrict the ability of candidates for public office to appear on the official ballot. Although it has scrutinized such restrictions with care, the Supreme Court has consistently endorsed the proposition that preventing voter confusion is a governmental interest of the highest order. ${ }^{31}$

Having been denied the most direct and effective methods of improperly influencing elec- tions, those seeking unfair electoral advantage inevitably turned to more subtle measures. Legislative responses did not lag far behind. The offense of electioneering, aimed originally at inhibiting outright intimidation of voters, gradually broadened to include any kind of electoral campaigning in the vicinity of the polling place. Today, the proscription includes activity that would be indisputably legitimate if carried on anywhere else, even if it is peaceful, wholly unthreatening, and involves nothing more than the communication of information. For example, many electioneering statutes prohibit the placing of posters or the distribution of campaign literature in the polling place. Intimidation has largely disappeared as an element of the crime.

In Burson v. Freeman, ${ }^{32}$ the Supreme Court ruled that these kinds of electioneering statutes do not violate the First Amendment. The Court took pains in Burson to try to place its decision within the tradition of cases upholding legislative measures to control "voter intimidation and election fraud." 33 Yet the Tennessee electioneering statute before the Court banned not only "the solicitation of votes" within 100 feet of the polls, but also "the display of campaign posters, signs or other campaign materials." 34 Clearly, there is no possibility that a campaign poster hung in the polling place can intimidate or defraud a voter.

The Court tipped its hand much more clearly when it observed that even though it takes only about 15 seconds to walk 75 feet, Tennessee

2916 Stat. 140 (1870).

30 See Ex parte Clark, 100 U.S. 399 (1879); Ex parte Siebold, 100 U.S. 371 (1879); Ex parte Yarbrough, 110 U.S. 651 (1884); In re Coy, 127 U.S. 731 (1888); United States v. Classic, 313 U.S. 299 (1941); but see United States v. Reese, 92 U.S. 214 (1876); United States v. Cruikshank, 92 U.S. 542 (1876).

31 See, for example, Bullock v. Carter, 405 U.S. 134 (1972); Lubin v. Panish, 415 U.S. 709 (1974); Storer v. Brown, 415 U.S. 724 (1974); Anderson v. Celebrezze, 460 U.S. 780 (1983).

32504 U.S. 191 (1992).

${ }^{33} I d$. at 206 (plurality op.).

${ }^{34}$ Id. at 193, quoting Tenn. Code Ann. § 2-7-111(b). See also Marlin v. District of Columbia Board of Elections \& Ethics, 236 F.3d 716 (D.C. Cir. 2001) (applying Burson to uphold an electioneering law as applied to the wearing of a campaign button in the polling place). 
could legitimately decide that "these last 15 seconds before its citizens enter the polling place should be their own, as free from interference as possible." ${ }^{35}$ The Court thus recognized the obvious. The problem with most contemporary electioneering is not that it makes voters fearful of voting their true inclinations. The problem with electioneering is that it raises the risk that voters will cast votes for the candidate whose name their eyes last happen to light upon before they enter the voting booth. Tennessee thus feared, and the Court agreed, that last-minute campaign appeals in the polling place have the potential to "dictate electoral outcomes." Cook and Burson thus have much in common. Indeed, the ballot labels at issue in Cook amount to nothing more than electioneering on the ballot itself, and they receive the same judicial treatment. Similarly, neither ruling is plausible unless it is in fact possible for voters to be decisively influenced by these kinds of random contacts with acontextual bits of political flotsam.

Lower courts have gone even further than the Supreme Court in recognizing not only the possibility and potential impact of irrational voting, but the many ways in which irrational or uninformed voters may be manipulated by subtle yet unscrupulous election practices at the polling place. For example, a significant body of case law has appeared prohibiting state and local election officials from systematically awarding the first position on the ballot to any particular group of candidates, such as incumbents. ${ }^{36}$ Cases invalidating this practice have generally relied on political science research suggesting that some voters who come to the polls without any information concerning the candidates for certain races will resolve their confusion by simply voting for the candidates listed first on the ballot. ${ }^{37}$ Some state courts have also developed a body of law dealing with the language of ballot measures, which they have applied to prohibit measures from being placed on the ballot not only if the measures are worded unclearly, but also if they are worded suggestively. ${ }^{38}$

Under this body of case law, voters get treated quite differently at the polling place than they are treated in their homes, during the campaign phase. Unlike the hardy, rational voters sketched in Buckley, voters at the polling place are seen as potentially ignorant, uninformed, and vulnerable to illicit suggestion. The Supreme Court, along with lower courts following its lead, seems to view the voting booth as a place of great potential danger to democratic self-rule. Voters entering this danger zone either have not made up their minds at all, or, if they have made up their minds, are at serious risk of losing their determination to follow through and vote their genuine preferences. In this environment, the state may regulate extensively to shield suggestible voters from improper influence and confusion. Moreover, as Cook v. Gralike illustrates, the state itself may not take any action, whether deliberately or inadvertently, that might influence these suggestible voters to cast their ballots in any particular way.

\section{NEUTRALIZING THE INCOMPETENT VOTER}

What explains this dichotomy in the Court's political sociology of voting behavior? Why does the Court treat voters as hardy, intelligent

35504 U.S. at 210.

${ }^{36}$ See Koppell v. New York State Board of Elections, 153 F.3d 95 (2d Cir. 1998); Sonneman v. Alaska, 969 P.2d 632 (Alaska 1998); New Alliance Party v. New York State Board of Elections, 861 F. Supp. 282 (S.D.N.Y. 1994); McLain v. Meier, 637 F.2d 1159 (8th Cir. 1980); Bloomenthal v. Lavelle, 614 F.2d 1139 (7th Cir. 1980); Sangmeister v. Woodard, 565 F.2d 460 (7th Cir. 1977), cert. denied, 435 U.S. 939 (1978); Gould v. Grubb, 536 P.2d 1337 (Cal. 1975); Bohus v. Board of Election Comm'rs, 447 F.2d 821 (7th Cir. 1971); Holtzman v. Power, 313 N.Y.S.2d 904 (Sup. Ct.), aff'd, 261 N.E.2d 666 (N.Y. 1970); Weisberg v. Powell, 417 F.2d 388 (7th Cir. 1969); Bolin v. Superior Court, 333 P.2d 295 (Ariz. 1958); Kautenburger v. Jackson, 333 P.2d 293 (Ariz. 1958); Elliott v. Secretary of State, 294 N.W. 171 (Mich. 1940); but see Graves v. McElderry, 946 F. Supp. 1569 (W.D. Okla. 1996); Clough v. Guzzi, 416 F. Supp. 1057 (D. Mass. 1976); Tsongas v. Secretary of the Commonwealth, 291 N.E.2d 149 (Mass. 1972).

${ }^{37}$ For a recent review of the relevant literature, see Joanne M. Miller and Jon A. Krosnick, The Impact of Candidate Name Order on Election Outcomes, 62 Public OpINION Q. 291 (1998).

38 See, for example, Boucher v. Bomhoff, 495 P.2d 77 (Alaska 1972); Thiel v. Priest, 28 S.W.3d 296 (Ark. 2000); City of Newport v. Gugel, 342 S.W.2d 517 (Ky. 1960); Guernsey v. Allan, 164 A.2d 496 (N.J. Sup. 1960). 
creatures in private, and credulous, suggestible weaklings in public?

1. Two-Stage Model of Voting Behavior: The most straightforward explanation for the Court's approach would be that it believes that formulating political opinions and voting them involve different kinds of competencies, and that American voters generally possess the one competence but not the other. Such a view, if the Court held it, would certainly be incoherent. It paints an unconvincing portrait of the voter, one all too reminiscent of the Cold War-era film The Manchurian Candidate. Consider: Waiting in line at the polling place to vote, the voter reads his local newspaper, including its editorial endorsements. These have no effect-or only whatever effect their reasoning and persuasiveness justifies-upon the independence or quality of the voter's judgment (Mills $v$. Alabama). Upon entering the voting booth, the voter lowers his paper and sees upon the ballot a message informing him that certain candidates have failed to support a term limits amendment. This message instantly reduces him to a condition of docile imbecility, and he immediately rejects all candidates identified as term limits scofflaws (Cook v. Gralike).

This is just not plausible. It is clear enough that voters can and do become confused at the polls; Florida's experience in the 2000 presidential election with "overvotes"-ballots that were punched for more than one presidential candidate-vividly demonstrated this intuitive proposition, which is in any event backed up by substantial research on ballot order and format. But there is no good reason to think that voters display any greater competence during the campaign phase of elections. Nearly five decades of research by political scientists has revealed starkly the degree to which the knowledge, political sophistication, and reasoning of contemporary voters falls short of classical republican ideals. This research has been aimed for the most part directly at the process by which voters formulate political choices, not the consistency and independence with which they cling in the voting booth to decisions made previously in private.

2. First Amendment Commitment to Voter Rationality: A second possible explanation for the Court's dual approach might be that the Court itself takes a more realistic view of the nature and scope of voter incompetence, yet feels compelled to ignore its view in First Amendment cases because the Court reads the First Amendment to commit us to an assumption of voter competence. It is always possible, of course, that the Constitution prohibits us from taking steps adequate to manage real and serious problems. Under the circumstances, however, this would be a strange reading of the Constitution. As shown above, the Court has issued numerous decisions upholding under other provisions of the Constitution government regulations premised on the theory that some (or many, or most) voters are not fully rational. It seems difficult to construct a plausible explanation for why the First Amendment should require the state to treat all voters as fully competent when the Equal Protection Clause permits the state to regulate fairly extensively on the basis of precisely the opposite assumption. Indeed, the Court in Cook construed Article I, $\S 4$ to prohibit the state from proceeding on the assumption that voters are exactly as hardy and independent-minded in the polling place as the Court's decision in Buckley deems them to be during the course of electoral campaigns. This is simply an incoherent reading of the Constitution, suggesting we must look elsewhere for an adequate explanation of the Court's approach.

3. Suppression of Speech as the Most Dangerous Remedy: A third possible explanation might focus not on underlying models of voting behavior, but on the remedies that governments seek to invoke to deal with problems raised by less than ideal voting behavior. On this view, the First Amendment, like any other provision of the Constitution, permits a government to view voters as incompetent, but it treats government suppression of political speech as more dangerous to the electoral process than any other form of government meddling. As a result, government 
restrictions designed to protect voters from confusion and undue influence during political campaigns cannot stand because they necessarily suppress speech, whereas similarly motivated restrictions at the polling place may be sustained because they merely regulate the environment in which the official act of voting itself takes place.

This explanation resonates well with the standard First Amendment presumption that government suppression of speech is bad, and perhaps it has influenced the Court's approach in these two lines of cases at some level. As a justification for the Court's dual approach, however, it is unpersuasive. To begin with, it rests upon a manifestly false premise. Government regulation of speech is far from the most dangerous kind of regulation of electoral processes. Danger, in this context, is a function of the degree to which government action threatens to control electoral results. Yet government regulation of voting qualifications and ballot access, to name just two obvious examples, has a far more direct and immediate impact on how elections turn out than does government meddling with political speech. Regulating who can vote, and for whom, can and clearly does decisively influence electoral outcomes, thus posing a far more urgent threat to popular sovereignty. Regulation of political speech during a campaign has, in comparison, a remote and attenuated impact on who actually wins elections. If government regulation of the act of voting is in fact far more threatening to popular sovereignty; and such regulation, though carefully scrutinized, is in fact often upheld; it follows that government regulation of political campaign speech ought to be easier to justify, not harder.

It might be objected at this point that government must regulate the voting process. Someone must decide who can vote, who can run, and how votes will be counted, and the only possible regulator is the government. Consequently, at least some government regulation of these processes must inevitably be sustained. The same cannot be said, the objection might continue, of political speech: it is simply not the case that po- litical speech must be regulated. This argument might well be valid, but it rests on an important assumption: that political speech is not in need of regulation because it simply is not dangerous to popular sovereignty. Both the argument in the preceding paragraph and this objection, it seems to me, point us in a more promising direction. The Court's dichotomous approach to government regulation of political campaigns and the polling place is best explained as resting on the Court's assumption that it is categorically impossible for political campaign speech to pose any significant risk to the fairness or integrity of electoral processes. Thus, the Court routinely strikes down regulations of campaign speech because it is unable to perceive any adequate justification for such regulations. In contrast, the Court readily perceives the legitimacy of threats to electoral integrity posed by behavior at the polling place, and consequently upholds regulations of such threats.

4. The Dangers of Government Electoral Speech: Before further exploring this more promising avenue, I want to dispose of a variation of the First Amendment explanation: that Cook and Buckley can be usefully distinguished on the ground that the former involves government rather than private speech, and that government speech in the electoral arena poses special dangers that justify its suppression. Here, at least, such an explanation is unavailing. In this context, government speech is capable of unduly threatening the electoral process only on the very set of assumptions that Buckley seems to deny-that voters are incapable of judging intelligently the accuracy of, and appropriate weight to be accorded to, speech from any particular source, including the government. Buckley, of course, deals directly only with voter susceptibility to private campaign speech. But treating government speech differently from private speech would make sense only if voters were somehow more susceptible to influence by government speech. This, in turn could be the case only if one of two things were true: either government speech is inherently more persuasive to voters than private speech, or the government's 
resources make it a potentially more potent electoral force than private actors. The first possibility seems false-if anything, the public seems to trust government speakers less than private speakers-and is in any event contradicted by the Court's identical treatment in Burson of private speech in the polling place. The second possibility, though more likely true, is ruled out expressly by Buckley.

Furthermore, the government speech analysis does not go very far in Cook even on its own terms. First, Cook is a particularly weak case to treat as presenting problems associated with government speech because of its content. In the electoral context, the principal danger presented by government political speech is the possibility that the government will speak for the purpose, and with the effect, of perpetuating its hold on power. In Cook, however, the speech at issue-promoting term limits-was designed to defeat self-perpetuation of the incumbent government. ${ }^{39}$ Second, even if the content of the speech were treated as irrelevant, the ballot labels at issue in Cook still do not present the characteristics that commentators typically identify as raising the most significant concerns about government speech. For example, the ballot labels do not communicate information that is unverifiable, or that is within the government's exclusive possession, or that concerns a subject that either has not or could not be extensively discussed in the public sphere. ${ }^{40}$ Indeed, if term limits are such a politically salient issue that the people of Arkansas saw fit to convey candidates' positions directly on the ballot, it is hard to imagine that these positions would not have been raised and thoroughly discussed during the campaign rather than solely on the ballot. Similarly, the Arkansas ballot labels do not raise the problem of government monopolization of speech markets identified by Abner Greene. ${ }^{41}$ Although the ballot is within the exclusive control of the state, there can be no good justification for treating the ballot itself as the relevant market for speech concerning term limits. The real market would seem to be the entire public sphere of campaign speech in the period preceding the election. ${ }^{42}$
5. The Neutralization Rationale: Is it possible, then, to fashion an account of the Court's election cases that explains its refusal to tolerate government regulation of political campaign speech without also attributing to the Court an unrealistically bifurcated model of voting behavior? I think it is. Such an account must turn on the Court's apparent belief that political speech, no matter how wrong, misleading or one-sided, does not present any significant threat to democratic self-governance even in view of voter incompetence. In other words, the Court's position is plausible only if the risk that incompetent voters will be unduly influenced by bad or misleading information is much worse at the polls than during the campaign. As we shall see, this view is cynical, but also plausible.

Let me make clear what I am not arguing. One reason why bad speech appearing during a political campaign might not cause any damage to the electoral process is because any problems it causes can be addressed and corrected later in the same campaign. As a matter of basic First Amendment doctrine, the Court generally contemplates that any

39 That, of course, is why these measures were so often generated by citizen initiatives.

${ }^{40}$ See Mark G. Yudof, When Government Speaks (1983). In a similar context involving the deletion of information submitted by candidates for inclusion in California's official voter information pamphlet, the Ninth Circuit observed: "The government makes no attempt to keep the material it deletes from the voters' pamphlet from reaching the public. The regulations would merely preclude the material from reaching the public through the government's voters' pamphlet, a single narrow forum." Geary v. Renne, 914 F.2d 1249, 1252 (9th Cir. 1990).

41 Abner S. Greene, Government of the Good, 53 VAND. L. REV. 1, 27-40 (2000).

${ }^{42}$ Of course, the ballot might well constitute the relevant market for political speech for a certain kind of voter, one who (1) reads and hears nothing before entering the polling place, and (2) is susceptible to manipulation by ballot labeling. But this merely brings us back to a problem of incompetent voting behavior rather than one involving heightened dangers of government electoral speech. Or at least, that is the case unless there is some reason to think that some substantial proportion of incompetent voters are more susceptible to coercion by public than by private speech, a phenomenon that is perhaps possible, though seemingly unlikely, and would tend to undermine the rationale for the Court's holding in Burson. 
problems caused by bad information will be rectified in the free market of political speech. As Justice Brandeis wrote, "the fitting remedy for evil counsels is good ones"; 43 the default solution for bad speech is more speech. But this reasoning does not apply to the problem of voter incompetence that the Court, in its polling place cases, has acknowledged. That is because the counterspeech solution assumes that voters are highly competent, for only a competent, rational, reasonably well-informed citizen can be reached and persuaded by counterspeech. The remedy of corrective campaign speech thus simply is not one that can be relied upon to solve the potential problems for the electoral system caused by voter incompetence.

To address voter incompetence, it is necessary to take a considerably more cynical view. Let us assume that voter incompetence, in some unknown degree, is a fact of modern political life. Let us assume further that nothing-including permitting unlimited counter-speech-can be done in the short term to prevent some proportion of the electorate from voting on the basis of inaccurate, inappropriate, superficial, or onesided information acquired during the course of the electoral campaign. Although irrational voting thus by hypothesis cannot be eliminated, its effects can be largely eliminated by taking steps to spread irrational votes as evenly as possible among the candidates. Irrational voters can thus be neutralized - taken out of the electoral calculus-by assuring that no single candidate or group of candidates receives a disproportionate windfall of irrational votes.

Over the course of a long campaign, it may be plausible to expect candidates and their supporters and opponents to take all possible steps to attract incompetent (as well as competent) voters, and that these efforts will, given time, result in a roughly even distribution of irrational votes. On this view, there is no need for government to regulate political speech that improperly sways irrational voters because it is unlikely that irrational voters will align so one-sidedly as to significantly affect an election. The same, however, cannot be said of appeals to incompetent voters made on the ballot itself, as in Cook. When an appeal to which incompetent voters are susceptible is made on the ballot, there is no opportunity for those who oppose the message to counter with irrational appeals of their own, whether directed to the same or to different voters. This makes it more likely that irrational votes will be cast in a single direction, in turn influencing electoral outcomes.

This is the precise theory upon which lower courts have invalidated laws establishing a ballot order that consistently lists incumbents (or any other group) first. Nobody claims that rotating the order in which candidates appear on different ballots will prevent incompetent voters from voting for the candidate listed first on the ballot. On the contrary, it is assumed that voters so inclined will continue to do so. However, rotation of ballot order will more likely result in an equal dispersion of such votes among all the candidates, reducing the impact of this particular kind of irrational voting on the outcome of the election. According to this reasoning, the defect in Cook was not so much that there was a message on the ballot as that the message was recurring, consistent, and focused on a single issue. The Arkansas law thus decreased the probability of a fair and even distribution of incompetent votes. In a close election, this might be decisive.

If this account is sound, there is nevertheless something disturbing about the inflexible way in which the Court applies the underlying principle. The Constitution, in the Court's view, apparently leaves no room for consideration of any actual facts about voting behavior or the mechanics of campaign and electoral processes. The Court, it seems, has irrevocably decreed that voter irrationality is not a constitutionally cognizable problem during electoral campaigns because it can be neutralized over the course of a campaign; and that it is a constitutionally cognizable problem at the polling place because it cannot be neutralized in that setting-and that is that.

This inflexibility leads to some disturbing anomalies in the Court's approach to electoral

${ }^{43}$ Whitney v. California, 274 U.S. 357, 375 (1927) (Brandeis, J., concurring). 
regulation. Congress, it will be recalled, conducted its own review of the problem of voter irrationality in electoral campaigns, and based FECA's remedies on precisely the kind of reasoning the Court applies in its polling place cases. By establishing campaign spending limits, Congress hoped to eliminate large inequalities in resources available to candidates. Presumably, equalization of resources would not in itself reduce the susceptibility of voters to irrational appeals; more likely, equalization of resources would allow candidates to distribute irrational votes approximately equally, neutralizing such votes and increasing the likelihood that federal elections would be decided on the basis of substantive appeals made to rational voters.

The Court rejected this theory in Buckley, and its default premise as I have sketched it herethat unconstrained campaign spending will most likely result in a fair dispersion of irrational votes-is not inherently implausible. Still, it is not at all clear why this default premise cannot be refuted by facts. If Congress believed, and could demonstrate, that unlimited political spending in fact results in significant financing disparities; and that better-financed candidates consistently attract more than their fair share of irrational votes; and that these irrational votes influence election outcomes often enough to make a systematic and arbitrary difference in favor of richer or betterfinanced candidates; it is hard to understand why Buckley's reasoning, especially in light of the polling place cases, ought not to permit a different result.

It would be one thing if the Court read the Constitution to dictate normatively some aspirational model of citizenship and voting behavior from which legislatures simply were not free to deviate. But that is not what the Court has done. On the contrary, it has freely acknowledged the very real problem of voter incompetence, and has construed the Constitution to permit that problem to be dealt with flexibly and reasonably effectively in certain circumstances. What is most disturbing about the Court's approach is that it seems to have based its constitutional decision making in this critically important area on a highly factbound, sociological model of individual behavior in the electoral arena, and then taken steps to assure that its model is not subject to contradiction by the facts. This is perhaps the very definition of judicial formalism, and it might help explain why, with each passing election cycle, the Court's adherence to Buckley seems increasingly unjustifiable.

Address reprint requests to: James A. Gardner University at Buffalo School of Law State University of New York John Lord O'Brian Hall Room 514 Amherst, NY 14260-1100 E-mail: jgard@buffalo.edu 